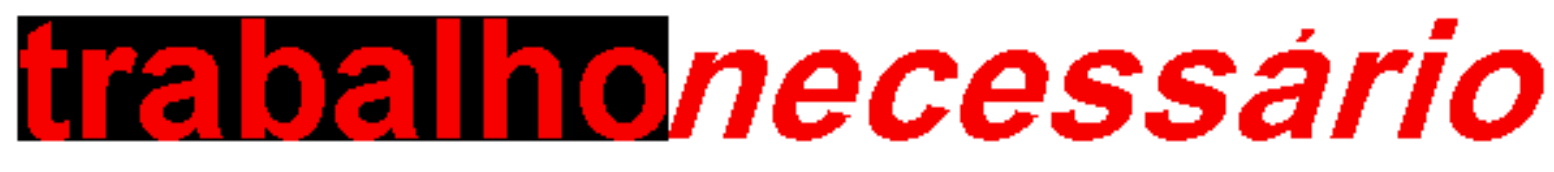

issn: $1808-799 \mathrm{X}$

ano 4 - número 4 - 2006

\title{
Em defesa do ciberleninismo1
}

Slavoj Zizek ${ }^{2}$

Nesta época de mudanças rápidas e contínuas, da "revolução digital" ao recuo a antigas formas sociais, mais que nunca o pensamento é exposto à tentação de "perder a coragem", de abandonar precocemente as antigas coordenadas conceituais. A mídia nos bombardeia constantemente com a necessidade de esquecer os "velhos paradigmas": para sobreviver, devemos modificar nossas idéias mais fundamentais de identidade pessoal, sociedade, meio ambiente etc.

A sabedoria da Nova Era afirma que estamos entrando numa era "pós-humana"; desde o surgimento da egopsicologia nos anos 30 , os psicanalistas estão "perdendo a coragem", baixando os braços (teóricos), apressando-se a admitir que a matriz edipiana da socialização não é mais operante, que vivemos numa época de perversão generalizada, que o conceito de "repressão" é inútil nestes tempos permissivos; o pensamento político pós-moderno nos diz que estamos entrando nas sociedades pós-industriais, em que as antigas categorias de trabalho, coletividade, classe etc. são zumbis teóricos, que não se aplicam mais à dinâmica da modernização...

A ideologia e prática política da Terceira Via é efetivamente o modelo dessa derrota, dessa incapacidade de reconhecer que o novo está aqui para permitir que $o$ antigo sobreviva. Contra essa tentação deveríamos seguir o modelo insuperado de Pascal e fazer a difícil pergunta: como podemos continuar fiéis ao antigo nas novas condições? Somente dessa maneira poderemos gerar algo efetivamente novo.

\section{Esquema natural}

Uma das ironias da história recente é que foi a antiga, infame e semi-esquecida dialética marxista das forças produtivas e das relações de produção que enterrou o socialismo realmente existente: o socialismo não foi capaz de suportar a passagem da economia industrial para a pós-industrial.

No entanto o capitalismo realmente oferece um esquema "natural" de relações de produção para o universo digital? Não existe na World Wide Web um potencial explosivo também para o próprio capitalismo? Talvez devamos nos arriscar aqui a rever as idéias de 
Lênin sobre como o caminho para o socialismo passa pelo terreno do monopólio capitalista, que podem parecer perigosamente ingênuas hoje:

"O capitalismo criou um aparato contábil na forma de bancos, sindicatos, serviço postal, associações de consumidores e de empregados de escritórios. Sem os grandes bancos, o socialismo seria impossível. (...) Nossa tarefa aqui é meramente podar o que capitalisticamente mutila esse excelente aparato e torná-lo ainda maior, ainda mais democrático, ainda mais abrangente. (...) Isso será uma escrituração nacional, uma contabilidade nacional da produção e distribuição de bens, será, por assim dizer, algo na natureza do esqueleto da sociedade socialista."

Contra essa citação, evidentemente é fácil tocar a melodia da "crítica da razão instrumental" e do "mundo administrado": os potenciais "totalitários" estão inscritos nessa própria forma de controle social total -na época de Stálin, o aparato administrativo social efetivamente se tornou "ainda maior"? Mas as coisas seriam realmente tão inequívocas?

E se substituirmos o exemplo (obviamente datado) do Banco Central pela World Wide Web, hoje o candidato perfeito a Intelecto Geral? Dorothy Sayers afirmou que a "Poética", de Aristóteles, é efetivamente a teoria das novelas policiais avant la lettre -como o pobre Aristóteles ainda não conhecia as novelas policiais, precisou discutir os únicos exemplos disponíveis, as medíocres e entediantes tragédias... Seguindo essa mesma linha, Lênin estava na verdade criando a teoria do papel da World Wide Web, mas, como não conhecia a WWW, teve de tratar dos infelizes bancos centrais. Consequentemente, também se poderia dizer que "sem a World Wide Web, o socialismo seria impossível. (...) Nossa tarefa aqui é meramente podar o que capitalisticamente mutila esse excelente aparato, torná-lo ainda maior, ainda mais democrático, ainda mais abrangente"?

A lição do monopólio da Microsoft não é então a leninista: em vez de combater seu monopólio por meio do aparato de Estado (lembre-se da divisão da Microsoft decretada pelos juízes), não seria mais "lógico" socializar a empresa, tornando-a livremente acessível?

O antagonismo-chave das chamadas novas indústrias (digitais) é o seguinte: como manter a forma de propriedade (privada) em que só a lógica do lucro se sustenta (lembrese também do problema do Napster)? E as complicações jurídicas na biogenética também não apontam na mesma direção? O elemento-chave dos novos acordos comerciais internacionais é a "proteção da propriedade intelectual": nas fusões em que uma grande companhia do Primeiro Mundo assume o controle de uma companhia do Terceiro Mundo, a primeira coisa que se faz sempre é fechar o departamento de pesquisa. Aqui surgem fenômenos que levam a idéia de propriedade a extraordinários paradoxos dialéticos: na Índia, as comunidades locais descobriram de repente que as práticas médicas e os materiais que usam há séculos hoje são de propriedade de empresas americanas, por isso têm de comprá-los delas; nas empresas de biogenética que patenteiam genes estamos descobrindo que partes de nós mesmos, nossos componentes genéticos, já estão patenteadas, são de propriedade alheia...

O que tudo isso significa é que a tarefa urgente da análise econômica hoje é repetir a "crítica da economia política" de Marx, sem sucumbir à tentação da multidão de ideologias 
das sociedades "pós-industriais". A mudança-chave envolve o status da propriedade privada: o elemento definitivo de poder e controle não é mais o último elo na cadeia de investimentos, a firma ou o indivíduo que "realmente possui" os meios de produção. 0 capitalista ideal hoje funciona de forma totalmente diferente: investe dinheiro emprestado, nada "'possui realmente", está mesmo endividado, mas não obstante controla o rumo das coisas.

Uma empresa é possuída por outra empresa, que também empresta dinheiro dos bancos, que podem em última instância manipular dinheiro de propriedade de pessoas comuns como nós. Com Bill Gates, a "propriedade privada dos meios de produção" tornase sem sentido, pelo menos no significado comum do termo.

O paradoxo dessa virtualização do capitalismo é afinal o mesmo do elétron na física de partículas elementares. A massa de cada elemento de nossa realidade se compõe da massa em repouso mais o excedente gerado pela aceleração de seu movimento; no entanto a massa de um elétron em repouso é zero, sua massa consiste apenas no excedente gerado pela aceleração de seu movimento, como se estivéssemos lidando com um nada que adquire certa substância ilusória simplesmente girando sobre si mesmo e gerando um excesso de si mesmo.

O capitalista ideal hoje funciona de forma totalmente diferente: investe dinheiro emprestado, nada "possui realmente", está mesmo endividado, mas não obstante controla o rumo das coisas; com Bill Gates, a "propriedade privada dos meios de produção" torna-se sem sentido, pelo menos no significado comum do termo

O capitalista virtual de hoje funciona de maneira semelhante -seu "valor líquido" é zero, ele opera diretamente apenas com o excedente, tomando emprestado do futuro. No entanto o resultado dessa crise da propriedade privada dos meios de produção não é de maneira alguma garantida -é aqui que devemos levar em conta o paradoxo máximo da sociedade stalinista: contra o capitalismo, que é a sociedade de classes, mas em princípio igualitária, sem divisões hierárquicas diretas, o stalinismo "maduro" é uma sociedade sem classes articulada em grupos hierárquicos precisamente definidos (a alta nomenclatura, a inteligência técnica, o Exército...). Talvez a ironia máxima da história seja que, assim como a visão de Lênin do "socialismo de Banco Central" só pode ser lida de maneira adequada retroativamente, por meio da World Wide Web, a União Soviética forneceu o primeiro modelo de sociedade desenvolvida "pós-propriedade", do verdadeiro "capitalismo tardio", em que a classe dominante será definida pelo acesso direto aos meios (informáticos, administrativos) de poder e controle social e a outros privilégios materiais e sociais: o importante não será mais possuir empresas, mas diretamente dirigi-las, ter o direito de usar um jato particular, ter acesso a assistência médica de alta qualidade etc. -privilégios que serão adquiridos não pela propriedade, mas por outros mecanismos (educacional, administrativo etc.).

\section{Produção imaterial}


A alternativa desqualificadora da teoria radical atual é: o que fazer a respeito da crescente importância da "produção imaterial" de hoje (cibertrabalhadores)? Insistimos que só os envolvidos na produção material "real" são a classe trabalhadora ou damos o terrível passo ao aceitar que os "trabalhadores simbólicos" são os (verdadeiros) proletários de hoje? Devemos resistir a esse passo, porque ele ofusca o papel central da separação entre produção imaterial e material, da divisão na classe trabalhadora (geralmente geográfica) entre cibertrabalhadores e trabalhadores materiais (programadores nos EUA ou na Índia, o trabalho suado na China ou na Indonésia).

Talvez a figura do desempregado seja o que representa hoje o proletário puro: a determinação básica dos desempregados continua sendo igual à dos trabalhadores, mas eles são impedidos de concretizá-la ou de renunciar a ela, por isso permanecem suspensos na potencialidade de trabalhadores que não podem trabalhar. Talvez em certo sentido hoje sejamos "todos desempregados": os empregos tendem cada vez mais a se basear em contratos de curta duração, de modo que o estado de desemprego é a regra, o nível zero, e o emprego temporário, a exceção.

\section{NOTAS}

(1) Publicado na Folha de São Paulo, Caderno Mais, em 2002. Tradução de Luiz Roberto Mendes Gonçalves.

(2) filósofo esloveno, professor do Instituto de Sociologia da Universidade de Liubliana 